\title{
PENGARUH RASIO KEUANGAN TERHADAP TINGKAT KINERJA PADA BANK PEMBANGUNAN DAERAH
}

\author{
Mulatsih \\ Universitas Gunadarma
}

\begin{abstract}
Effect of Financial Ratios on Performance at Regional Development Banks. The aim of this research is to analyze the effect of financial ratios on profitability at regional development banks. The method analysis that used in this research is multiple regressions with six variabel independent such as capital adequacy ratio, net interest margin, BOPO, loan to deposit ratio, non-performing loan, and return on equity, and the dependent variables is return on asset. The result shown that capital adequacy ratio, net interest margin, and ROE have a positive influence on ROA. BOPO and non-perfoming loan had a negative influence to return on asset. The value of $R$ square shown that all the independent variables can explained the model with $83,7 \%$, and the rest is about $16,7 \%$ was explained by other variables outside the model.
\end{abstract}

Keywords: financial ratio, profitability, multiple regressions

\begin{abstract}
Abstrak. Pengaruh Rasio Keuangan Terhadap Tingkat Kinerja Pada Bank Pembangunan Daerah. Tujuan penelitian ini ialah untuk menganalisis pengaruh rasio keuangan terhadap tingkat profitabilitas di Bank Pembangunan Daerah. Metode analisis yang dipergunakan dalam penelitian ini ialah regresi berganda dengan enam variabel bebas seperti rasio kecukupan modal (CAR), net interest margin (NIM), BOPO, loan to deposit ratio (LDR), non-performing loan (NPL), and return on equity (ROE), serta variabel dependennya ialah return on asset (ROA). Hasil yang ada menunjukkan bahwa CAR, NIM, ROE memiliki pengaruh yang positif terhadap ROA. Sedangkan BOPO dan NPL memiliki pengaruh yang negatif terhadap ROA. Nilai R-square menunjukkan bahwa variabel independen mampu menjelaskan model ini sebesar 83,7\% dan sisanya 16,7\% dijelaskan oleh variabel lain di luar model.
\end{abstract}

Kata Kunci: rasio keuangan, profitabilitas, regresi berganda 


\section{PENDAHULUAN}

Pesatnya perkembangan dunia perbankan dewasa ini dapat berpengaruh terhadap kinerja suatu bank. Semakin tingginya kompleksitas usaha perbankan dapat menjadi faktor pemicu meningkatnya risiko-risiko yang dihadapi suatu bank terutama risiko kredit bermasalah atau lebih dikenal dengan istilah kredit macet. Masalah yang sering dihadapi oleh perbankan di Indonesia antara lain banyak disebabkan oleh depresiasi rupiah, peningkatan suku bunga Sertifikat Bank Indonesia (SBI), sehingga menimbulkan meningkatnya masalah yang berkaitan dengan kredit. Pengawasan internal bank yang lemah, seperti rendahnya manajemen risiko bank serta modal bank yang tidak dapat meliputi terhadap risiko-risiko yang dihadapi oleh bank dapat mengakibatkan menurunnya tingkat kinerja bank tersebut.

Sebagaimana kita ketahui bahwa bank merupakan suatu lembaga intermediasi keuangan yang umumnya didirikan untuk menghimpun dana dan menyalurkannya kembali kepada masyarakat. Menurut UU RI No 10 Tahun 1998 tanggal 10 November 1998 tentang perbankan, dapat disimpulkan bahwa usaha perbankan meliputi tiga kegiatan, yaitu menghimpun dana, menyalurkan dana, dan memberikan jasa bank lainnya. Kegiatan menghimpun dan menyalurkan dana merupakan kegiatan pokok bank sedangkan memberikan jasa bank lainnya hanya kegiatan pendukung. Kegiatan menghimpun dana, berupa mengumpulkan dana dari masyarakat dalam bentuk simpanan giro, tabungan, dan deposito. Bank merupakan sarana yang memudahkan aktivitas masyarakat untuk menyimpan uang, dalam hal perniagaan, maupun untuk investasi masa depan. Dunia perbankan merupakan salah satu institusi yang sangat berperan dalam bidang perekonomian suatu negara (khususnya di bidang pembiayaan perekonomian). Mengingat bahwa bank merupakan lembaga yang dalam kegiatan usahanya mengandalkan kepercayaan masyarakat, maka kesehatan bank tersebut harus tetap terpelihara. Pemeliharaan terhadap tingkat kesehatan bank dilakukan dengan menjaga likuiditas, solvabilitas dan rentabilitas bank tersebut agar bank dapat memenuhi kewajiban terhadap semua pihak yang menggunakan jasa bank, terutama 
kepada para nasabah yang akan melakukan transaksi penarikan maupun pencairan simpanan sewaktu-waktu.

Penting bagi bank untuk menjaga kepercayaan dari suatu masyarakat, mengingat bahwa kegiatan utama bank adalah menghimpun dana dari masyarakat kemudian menyalurkannya kembali dalam bentuk kredit kepada masyarakat untuk memperoleh pendapatan bunga dari kredit yang disalurkan. Oleh karena itu, Bank Indonesia membuat suatu peraturan tentang penilaian tingkat kesehatan bank. Menurut peraturan bank Indonesia nomor 13/1/ PBI/2011 Pasal 2 tentang penilaian tingkat kesehatan bank umum, disebutkan bahwa: Pertama, bank wajib memelihara dan/atau meningkatkan Tingkat Kesehatan Bank dengan menerapkan prinsip kehati-hatian dan manajemen risiko dalam melaksanakan kegiatan usaha. Kedua, dalam rangka melaksanakan tanggung jawab dan kelangsungan usaha bank, direksi dan dewan komisaris bertanggungjawab untuk memelihara dan memantau tingkat kesehatan bank dan mengambil langkah-langkah yang diperlukan untuk memeliharadan/atau meningkatkan Tingkat Kesehatan Bank sebagaimana dimaksud pada ayat (1).

Dalam Peraturan Bank Indonesia nomor 13/1/ PBI/2011 juga dijelaskan bahwa bank wajib melakukan penilaian sendiri (self assessment) atas tingkat kesehatan bank. Adapun tingkat kesehatan bank dapat diartikan sebagai kemampuan suatu bank untuk melakukan kegiatan operasional perbankan secara normal dan mampu memenuhi semua kewajibannya dengan baik dan sesuai dengan peraturan perbankan yang berlaku. Adapun aturan tentang kesehatan bank yang diterapkan oleh Indonesia meliputi berbagai aspek kegiatan antara lain kemampuan bank dalam menghimpun dana, kemampuan bank dalam mengelola dana, kemampuan untuk menyalurkan dana ke masyarakat, kemampuan untuk memenuhi kewajiban kepada pihak lain dan pemenuhan peraturan yang berlaku (Estiningsih, 2011). Secara sederhana dapat dikatakan bahwa bank yang sehat adalah bank yang dapat menjalankan fungsi-fungsinya dengan baik. Dengan kata lain, bank yang sehat adalah bank yang dapat menjaga dan memelihara kepercayaan masyarakat, dapat menjalankan fungsi intermediasi, dapat membantu kelancaran lalu lintas pembayaran serta dapat digunakan oleh pemerintah dalam melaksanakan 
berbagai kebijakannya, terutama kebijakan moneter. Dengan menjalankan fungsi-fungsi tersebut diharapkan dapat memberikan pelayanan yang baik kepada masyarakat serta bermanfaat bagi perekonomian secara keseluruhan. Untuk dapat menjalankan fungsinya dengan baik, bank harus mempunyai modal yang cukup, menjaga kualitas asetnya dengan baik, dikelola dengan baik dan dioperasikan berdasarkan prinsip kehati-hatian, menghasilkan keuntungan yang cukup untuk mempertahankan kelangsungan usahanya, serta memelihara likuiditasnya sehingga dapat memenuhi kewajibannya setiap saat. Selain itu, suatu bank harus senantiasa memenuhi berbagai ketentuan dan aturan yang telah ditetapkan, yang pada dasarnya berupa berbagai ketentuan yang mengacu pada prinsip-prinsip kehati-hatian di bidang perbankan.

Kondisi kesehatan suatu bank dapat kita lihat dari kinerja bank yang dapat kita analisis dari laporan keuangan yang disajikan oleh bank. Dari laporan keuangan tersebut dapat kita ketahui apakah bank dapat mencapai suatu tingkat efisiensi yang baik dengan mengelola sumber-sumber dana yang ada untuk mendapatkan return yang optimal. Bank yang memiliki tingkat kesehatan yang baik, dapat mendorong kepercayaan bagi masyarakat untuk tetap menyimpan dananya pada bank tersebut. Sebaliknya, bank yang diberi kepercayaan oleh masyarakat untuk mengelola dananya juga sadar bahwa mereka diberi tanggungjawab untuk mengelola sumber-sumber dana yang dimiliki secara optimal. Di sisi lain, sebagai dasar untuk pengambilan keputusan, investor juga melihat informasi fundamental yang bersumber dari laporan keuangan. Laporan keuangan yang disajikan oleh perusahaan merupakan suatu bentuk pertanggungjawaban manajemen kepada pemilik (owner) perusahaan, karena dari laporan keuangan tersebut dapat dilihat kinerja dari manajemen, sehingga menjadi pertimbangan investor untuk mengambil keputusan berkaitan dengan investasi yang akan dilakukan ke perusahaan tersebut. Dengan laporan keuangan yang disajikan, investor akan melakukan analisis terhadap kinerja perusahaan sehingga dapat memprediksi kinerja perusahaan dan eksistensinya dimasa yang akan datang.

Dalam penilaian kinerja keuangan perbankan dalam penelitian ini sedikit berbeda dengan kriteria penilaian yang diterapkan oleh Bank Indonesia. 
Sebagaimana telah kita ketahui bahwa penilaian kesehatan bank menurut peraturan bank Indonesia mengacu pada rasio CAMELS (Capital, Assets Quality, Management, Earning, Liquidity dan Sensitivity to Market), sedangkan dalam penelitian ini tidak memasukkan unsur manajemen karena tidak bisa dilihat dari luar. Penelitian ini menggunakan rasio-rasio keuangan yang umum digunakan oleh bank untuk menilai kinerja keuangan bank. Dari rasio-rasio keuangan bank dan dengan melihat trend pertumbuhannya dari tahun ke tahun maka dapat digunakan juga untuk memprediksi tingkat kebangkrutan suatu bank.

Mengingat bank sebagai lembaga keuangan yang dipercaya oleh masyarakat untuk mengelola dana dan menyalurkan dananya kepada masyarakat atau lebih dikenal dengan istilah agent of trust, maka industri perbankan perlu memperkuat kinerja keuangannya. Dengan melihat variabelvariabel yang digunakan untuk meneliti tingkat kesehatan bank dan melakukan analisis terhadap rasio-rasio keuangan bank, maka permasalahan yang dapat penulis rumuskan antara lain: Pertama, apakah rasio-rasio keuangan CAR, NIM, BOPO, NPL, LDR dan ROE berpengaruh terhadap kinerja keuangan Bank Pembangunan Daerah yang diukur dengan ROA? Kedua, variabel-variabel keuangan manakah yang paling dominan berpengaruh terhadap kinerjaBank Pembangunan Daerah yang beroperasi di Indonesia?

Berdasarkan rumusan masalah yang telah penulis uraikan diatas, maka tujuan dari penelitian ini adalah : Pertama, menganalisis pengaruh rasio-rasio keuangan CAR, NIM, BOPO, NPL, LDR, dan ROE terhadap kinerja Bank Pembangunan Daerah diukur dengan ROA. Kedua, menganalisis variabelvariabel keuangan yang paling dominan untuk mempengaruhi kinerja keuangan Bank Pembangunan Daerah diukur dengan ROA.

\section{METODE}

Obyek penelitian dalam penelitian ini adalah laporan keuangan Bank Pembangunan Daerah. Metode pengumpulan data yang digunakan dalam penelitian ini adalah dengan cara mendownload data laporan keuangan publikasi bank yang terdapat di website Bank Indonesia tahun 2006-2008. Variabel-variabel yang digunakan dalam penelitian ini terdiri dari tujuh macam 
variabel yang terdiri dari enam variabel independen dan satu variabel dependen. Adapun Varibel independen dalam penelitian ini antara lain: CAR, NIM, BOPO, LDR, NPL, dan ROE dan variabel dependen dalam penelitian ini adalah ROA. Analisis ini digunakan untuk mengetahui pengaruh antara variabel CAR, NIM, BOPO, NPL, LDR dan ROE terhadap Variabel ROA.

Formula :

$Y=a+b_{1} X_{1}+b_{2} X_{2}+b_{3} X_{3}+b_{4} X_{4}+b_{5} X_{5}+b_{6} X_{6}+\varepsilon$

Dimana :

$\mathrm{Y} \quad=$ kinerja perbankan yang dicerminkan dengan variabel ROA

$\mathrm{X}_{1} \quad$ = Capital Adequacy Ratio (CAR)

$\mathrm{X}_{2}=$ Net Interest Margin (NIM)

$\mathrm{X}_{3}=\mathrm{BOPO}$

$\mathrm{X}_{4} \quad=$ Non Performing Loan (NPL)

$\mathrm{X}_{5} \quad=$ Loan to Deposit Ratio (LDR)

$\mathrm{X}_{6}=$ Return on Equity (ROE)

$\varepsilon \quad=$ faktor lain diluar model

Dalam penelitian ini hipotesis diuji melalui tiga macam pengujian, yaitu :

Uji F atau uji simultan, uji t atau uji parsial, dan uji koefisien determinasi $\left(\mathrm{R}^{2}\right)$. Pengaruh pengujian terhadap variabel independen $(X)$ secara bersama sama atau simultan terhadap variabel dependen (Y). Pengujian ini digunakan untuk menguji pengaruh Koefisien determinasi digunakan untuk mengetahui persentase besarnya perubahan variabel terikat $(\mathrm{Y})$ oleh variabel bebas $(\mathrm{X})$, atau dengan kata lain koefisien determinasi merupakan persentase pengaruh varibel bebas terhadap nilai variabel terikat.

\section{PEMBAHASAN}

Dari pengolahan data dapat diketahui bahwa nilai minimum CAR adalah sebesar 13,70 \%, nilai maksimum CAR adalah sebesar 46,46 \% dan nilai ratarata CAR sebesar 13,70\%. Hal tersebut memberikan indikasi bahwa rata-rata keseluruhan Bank Pembangunan Daerah yang beroperasi di Indonesia selama tahun 2006-2008 mempunyai CAR yang tinggi dan berada diatas ketentuan Bank Indonesia (8\%), sehingga Bank Pembangunan Daerah dapat dikatakan 
mampu memenuhi kecukupan modal minimum karena angka rata-rata rasio kecukupan modal (CAR) berada diatas 8\%.

Dari hasil olahan data dapat diketahui bahwa variabel BOPO memiliki nilai minimum sebesar 45,33\%, nilai maksimum sebesar $64,78 \%$ dan nilai ratarata sebesar 56,79\%. Hal ini mengindikasikan bahwa Bank Pembangunan Daerah memiliki tingkat efisiensi yang baik yaitu angka rata-rata BOPO sebesar $56,79 \%$ berada di bawah 94,00\% (ketentuan BOPO maksimum Bank Indonesia). Hal ini berarti bank-bank di Indonesia dapat melakukan efisiensi terhadap biaya operasionalnya dan pendapatan operasional bank yang berada diatas biaya operasional yang dikeluarkan Bank Pembangunan Daerah, sehingga dapat dikatakan bahwa Bank Pembangunan Daerah sehat.

Variabel NIM mempunyai nilai minimum sebesar 1,58\%, nilai maksimum 6,98\% dan nilai rata-rata sebesar 9,49\%. Rata-rata NIM yang menunjukkan angka sebesar 9,49\% menunjukkan bahwa Bank Pembangunan Daerah mampu mendapatkan bunga bersih sebesar 9,49\% yang berasal dari penggunaan aktiva produktifnya. Hal ini berarti bahwa kemampuan bank dalam menyalurkan kredit kepada masyarakat dan mendapatkan pendapatan yang berasal dari bunga kredit tinggi.

Variabel LDR memiliki nilai minimum 21,97\%, nilai maksimum sebesar $107,52 \%$ dan nilai rata-rata sebesar 57,29\%. Dilihat dari nilai minimum,nilai maksimum dan nilai rata-rata LDR, mengindikasikan bahwa bank mampu menyalurkan kreditnya dengan baik. Semakin tinggi kredit yang diberikan kepada masyarakat, berarti semakin besar kemungkinan pendapatan yang akan diterima bank yang berasal dari bunga kredit.

Variabel NPL menunjukkan nilai minimum sebesar 0,07\%, nilai maksimum 5,57\% dan nilai rata-rata sebesar 1,02\%. Dilihat dari nilai minimum dan nilai rata-rata LDR, hal ini mengindikasikan bahwa Bank Pembangunan Daerah belum mampu menyalurkan kreditnya secara optimal, karena menurut ketentuan Bank Indonesia tentang ambang batas penentuan kredit adalah minimum sebesar $5 \%$.

Variabel ROA memiliki nilai minimum sebesar 1,58\%, nilai maksimum sebesar 6,98\% dan nilai rata-rata sebesar 3,51 \%. Hal ini mengindikasikan 
bahwa kemampuan bank untuk mendapatkan pendapatan dari aktiva produktif sangat tinggi. Semakin besar nilai ROA, berarti kinerja bank semakin baik.

Salah satu cara untuk mendeteksi adanya multikolienaritas dilakukan dengan cara mengkorelasikan antar variabel bebas dan apabila korelasinya tinggi (lebih besar dari 0,8) maka antar variabel bebas tersebut terjadi multikolienaritas. Berdasarkan hasil pengujian, tampak bahwa nilai toleransi lebih besar dari 0,1 dan nilai VIF kurang dari 10, maka dapat dikatakan bahwa tidak terjadi multikolienaritas dalam penelitian ini.

Pengujian heteroskeastisitas bertujuan untuk menguji apakah dalam model regresi terjadi ketidaksamaan variance dari residual suatu pengamatan ke pengamatan yang lain. (Ghozali, 2005). Jika variance dari residual suatu pengamatan ke pengamatan lain tetap, maka disebut homoskedastisitas dan jika berbeda disebut heteroskedastisitas. Model regresi yang baik adalah yang tidak terjadi heteroskedastisitas (Ghozali,2005). Dari gambar scatter plot dapat dikatakan bahwa tidak terjadi heteroskedastisitas, karena titik-titik yang terdapat dalam grafik tersebut tersebar dan tidak membentuk pola tertentu dan titik-titik tersebut diatas dan dibawah angka 0 pada sumbu Y.

Uji autokorelasi bertujuan untuk menguji apakah dalam model regresi linier ada korelasi antara keslahan pengganggu pada periode $t$ dengan kesalahan pengganggu pada periode t-1 (sebelumnya).Jika terjadi korelasi, maka dinamakan ada masalah autokorelasi. Untuk mengetahui ada tidaknya autokorelasi dalam suatu model regresi, maka dapat dilakukan dengan menggunakan uji dw atau uji durbin-watson. (Algifari, 1997). Berdasarkan hasil pengujian dengan spss dapat dilihat bahwa nilai dw sebesar 2,243, berarti dapat ditarik kesimpulan bahwa tidak ada atau tidak terjadi autokorelasi dalam penelitian ini.

Dalam penelitian ini analisis statistik yang digunakan adalah analisis regresi linier berganda, analisis ini dilakukan dengan tujuan untuk mengetahui besarnya pengaruh dari variabel-variabel independen yaitu: CAR, BOPO, NIM, NPL, LDR, ROE terhadap variabel ROA.

Berdasarkan tabel diatas, maka persamaan regresi linier dapat disusun sebagai berikut: 
ROA $=7,492+0,055 \mathrm{CAR}-0,142 \mathrm{BOPO}+0,087 \mathrm{NIM}+0,019 \mathrm{LDR}-0,026 \mathrm{NPL}$

$$
+0,028 \mathrm{ROE}+\varepsilon
$$

Dari persamaan regresi tersebut, maka dapat dijelaskan bahwa setiap kenaikan satu satuan pada rasio CAR akan menaikkan 0,055 satuan pada ROA. Dilihat dari tabel diatas, CAR memiliki trend yang positif, artinya setiap kenaikan CAR maka semakin menaikkan ROA bank. CAR yang semakin meningkat mengindikasikan bahwa tingkat kecukupan modal bank semakin baik sehingga operasional bank berjalan dengan lancar dan meningkatkan kinerja keuangan bank yang diukur dari ROA, yang berarti semakin meningkatnya pendapatan yang diperoleh oleh bank, maka ROA bank semakin tinggi.

Setiap kenaikan satu satuan rasio BOPO, maka akan menurunkan 0,142 satuan ROA. Dari persamaan regresi diatas dapat dilihat bahwa BOPO memiliki trend yang negatif, hal ini berarti bahwa semakin besar rasio BOPO berarti semakin menurunkan kinerja Bank Pembangunan Daerah yang diukur dari ROA, karena semakin besar biaya operasional yang dikeluarkan oleh Bank Pembangunan Daerah dibandingkan dengan pendapatan operasional yang diterima oleh bank. Semakin tingginya rasio BOPO berarti menunjukkan kinerja bank tersebut buruk.

Setiap kenaikan satu satuan rasio NIM, maka akan meningkatkan 0,087satuan ROA. Rasio NIM pada Bank Pembangunan Daerah menunjukkan trend positif, hal ini berarti bahwa semakin besar nilai NIM, maka semakin besar pula ROA bank. Semakin tingginya nilai NIM berarti bahwa semakin besar pendapatan bersih yang diperoleh oleh Bank Pembangunan Daerah yang berasal dari penggunaan aktiva produktif.

Setiap kenaikan satu satuan rasio LDR, maka akan menaikkan 0,019 satuan ROA. Rasio LDR menunjukkan trend yang positif. Hal ini berarti bahwa meningkatnya rasio LDR berarti ROA bank juga akan mengalami kenaikan. Rasio LDR yang semakin besar berarti bahwa bank mampu untuk memenuhi pembayaran kembali deposito yang telah jatuh tempo oleh nasabah. Semakin tinggi rasio LDR suatu bank, berarti bahwa ROA bank semakin meningkat dan semakin meningkat pula kinerja daripada bank tersebut. 
Setiap kenaikan 1 satuan rasio NPL, maka akan menurunkan 0,026 satuan ROA. Rasio NPL menunjukkan trend negatif yang berarti bahwa setiap kenaikan rasio NPL akan menurunkan kinerja bank pembangunan daerah karena dengan semakin tingginya kredit macet, maka pendapatan bank yang berasal dari bunga kredit akan semakin menurun, sehingga menurunkan kinerja bank.

Setiap kenaikan 1 satuan ROE, maka akan meningkatkan 0,028 satuan ROA. Hal ini berarti bahwa semakin besar ROE, maka semakin besar pula ROA bank tersebut. Semakin tingginya ROA bank memberikan indikasi bahwa kinerja bank tersebut semakin bagus.

Dari uraian tersebut diatas dapat diketahui bahwa variabel bebas yang paling berpengaruh terhadap ROA adalah variabel NIM dengan koefisien 0,087 kemudian diikuti dengan variabel CAR dengan koefisien 0,055, variabel ROE dengan koefisien 0,028, dan variabel LDR dengan koefisien 0,019. Variabel yang paling rendah pengaruhnya terhadap ROA yaitu variabel BOPO dengan koefisien $-0,142$ dan variabel NPL dengan koefisien -0,026. Dari uraian tersebut dapat diketahui bahwa variabel CAR, NIM,ROE dan LDR berpengaruh positif terhadap ROA, sedangkan variabel NPL dan BOPO berpengaruh negatif terhadap ROA.

Dilihat dari hasil dapat diketahui bahwa $\mathrm{R}^{2}$ sebesar 0,837 , yang berarti bahwa 83,7\% ROA dipengaruhi oleh keenam variabel bebas CAR, BOPO, NIM, LDR, NPL, dan ROE. Sedangkan sisanya 16,7 \% dipengaruhi oleh faktor lain yang tidak dimasukkan dalam model. Uji F atau uji simultan merupakan pengujian yang dilakukan dengan membandingkan antara nilai $\mathrm{F}$ tabel dengan nilai $\mathrm{F}$ hitung yang terdapat dalam tabel analysis of variance. Hasil perhitungan uji $\mathrm{F}$, dapat diketahui bahwa $\mathrm{F}$ hitung sebesar 16,308 dengan nilai signifikansi sebesar 0,000. Hal ini berarti bahwa nilai probabilitas kurang dari 0,05, sehingga H0 ditolak dan Ha diterima yang berarti bahwa variabel CAR, BOPO, NIM, LDR, NPL dan ROE secara bersama-sama berpengaruh terhadap variabel ROA.

\section{SIMPULAN}

Berdasarkan hasil analisis terhadap pengaruh variabel CAR, BOPO, NIM, NPL, LDR dan ROE terhadap variabel ROA, dengan menggunakan analisis 
regresi linier berganda maka dapat diambil simpulan sebagai berikut. Variabel CAR memberikan pengaruh yang positif dan signifikan terhadap variabel ROA. Variabel BOPO memberikan pengaruh yang negatif dan signifikan terhadap variabel ROA. Variabel NIM memberikan pengaruh yang positif tetapi tidak signifikan terhadap variabel ROA. Variebel LDR memberikan pengaruh yang positif dan signifikan terhadap variabel ROA. Variabel NPL memberikan pengaruh yang negatif dan tidak signifikan terhadap variabel ROA. Variabel ROE memberikan pengaruh yang positif tetapi tidak signifikan terhadap variabel ROA. Variabel-variabel yang paling dominan berpengaruh terhadap tingkat kesehatan bank yang diukur dengan rasio ROA adalah variabel NIM, LDR, ROE dan CAR.

Nilai $\mathrm{R}^{2}$ sebesar 0,837, yang berarti bahwa 83,7\% ROA dipengaruhi oleh keenam variabel bebas CAR, BOPO, NIM, LDR, NPL, dan ROE. Sedangkan sisanya $16,7 \%$ dipengaruhi oleh faktor lain yang tidak dimasukkan dalam model. Hasil perhitungan uji F, dapat diketahui bahwa F hitung sebesar 16,308 dengan nilai signifikansi sebesar 0,000. Hal ini berarti bahwa variabel CAR, BOPO, NIM, LDR, NPL dan ROE secara bersama-sama berpengaruh terhadap variabel ROA.

\section{PUSTAKA ACUAN}

Arafat, M.Y. et.al. 2001. Analysis of Bank's Performance and Efficiency in Indonesia. The Journal of Finance.Vol.7, No 2.

Herwany, A. \& M. Anwar. 2006. The Determinants of Successful Bank Profitability in Indonesia: Empirical Study for Profincial Governmen's Banks and Private Non-foreign Banks. The Journal of Finance.Vol 6, no 3.

Basran, D. 2005. Analisis Faktor-faktor Yang Berpengaruh Terhadap Kinerja Bank Umum Di Indonesia Tahun 2001-2003. (Tesis Tidak Dipublikasikan). Semarang: Magister Manajemen Universitas Diponegoro.

Dendawijaya, L. 2005, Manajemen Perbankan. Jakarta: Ghalia Indonesia.

Ghozali, I. 2005. Aplikasi Analisis Multivariate Dengan Program SPSS. Semarang: Badan Penerbit Universitas Diponegoro.

Mulyaningrum, P. 2008. Pengaruh Rasio Keuangan terhadap Kebangkrutan Bank di Indonesia. (Tesis Tidak Dipublikasikan). Semarang: Pasca Sarjana Universitas Diponegoro. 
Prasnanugraha, P. 2007. Analisis Pengaruh Rasio-Rasio Keuangan terhadap Kinerja Bank Umum di Indonesia. (Tesis Tidak Dipublikasikan). Semarang: Program Pasca Sarjana Universitas Diponegoro.

Surat Edaran Bank Indonesia No 3/30 DPNP tgl 14 Desember 2001. Perihal Laporan Keuangan Publikasi Bank Umum kepada Bank Indonesia. Jakarta: Bank Indonesia.

Surat Edaran Bank Indonesia No 6/73/Intern DPNP tgl 24 Desember 2004. Perihal Pedoman Sistem Penilaian Tingkat Kesehatan Bank Umum (CAMELS Rating). Jakarta: Bank Indonesia.

Suyono, A. 2005. Analisis Rasio-rasio Bank yang Berpengaruh terhadap Return on Asset(ROA). (Tesis Tidak Dipublikasikan). Semarang: Magister Manajemen Universitas Diponegoro. 